\title{
Clearing the Forest: Colonialism and Deforestation in Nagaland, Northeast India
}

\author{
S. Victor Babu \\ Department of History Babasaheb Bhimrao Ambedkar University, Lucknow, India
}

\begin{abstract}
Despite emergence of conservative ideas of forest, desire of Empire building among the colonialists made them world leader in deforestation. In continuation of this polity, the British exploited natural resources from its colonies in Indian subcontinent and Africa etc. There are examples witnessing the disappearance of several tree species from the forest like oak forest in England. As it is well known that Indian subcontinent is prosperous in its natural resources, the British started tapping the natural resources of the country. British started giving preferential treatment to some tree species over the others there by affecting the diversity of the forests. British aim was to retain all valuable species and remove all the inferior species. This shows that British exploited the natural resources of the country to the fullest during its regime. This paper is an attempt to explain deforestation in Nagaland during colonial period. It further tries to reveal the true motive of British in India behind exploiting the natural resources for their profit against the background of rhetoric of conservation of Natural resources.
\end{abstract}

Keywords: Deforestation, Nagaland, Exploitation of Natural Resources, Valuable Species, British Era etc.

\section{Introduction}

Britain had emerged globally, by around 1860 as the world leader in deforestation, devastating its own woods and the forests of Ireland, South Africa, and north eastern United States to draw timber for ship building, iron-smelting and farming. The early treatment of Indian forests by the British Raj confirmed the view held by many that the British were responsible for the beginning of the process of depletion of India's forest wealth. With Oaks forests vanishing in England, a permanent supply of durable timber was required for the Royal Navy as the safety of the empire depended on its wooden walls. In a period of fierce competition between the colonial powers, Indian teak, the most durable of shipbuilding timbers, saved England during the war with Napoleon and later maritime expansion. As late as the1880s the Indian Forest Department was entertaining repeated requests from the British Admiralty for the supply of Madras and Burma Teak. The interest in teak was predictably dictated by imperialistic consideration for revenue and timber for defence. The imperial forest department in India was established in 1864, however, it was only in the year 1868 that an Assistant Conservator was deputed to inspect and report on the forests of Assam. After the general inspection of the Assam forests was completed in 1869-70, the special examination, with a view of selecting reserves commenced and experimental timber and plantation works were started in 1870- 71.

\section{Nagaland}

The present state of Nagaland was a district in the province of Assam under the British colonial administration. Tracts of forest lands were declared as reserved forest in the Naga Hills as well as transferred from one district to another for the convenience of the British administration and for future exploitation of the forests. From 1874 onwards there was gradual extension of colonial forest policy into the Naga Hills because prior to that, the information received from the civil authorities regarding the forests was insufficient even to prepare a map or to give a comprehensive description of those forests in Assam. However it has to be noted that, deforestation was evidently happening even in the Nagaland district of Assam due to the demand of timber markets in Sylhet and East Bengal. After exhausting the un-classed State forests around Dimapur, the timber merchants who had been cutting trees there to supply markets in Sylhet and East Bengal were on the lookout for suitable areas. This in turn led to the reservation of Rangapahar forest in 1913. Thus, any well stocked forest, being generally of useful species was reserved with the intention of future exploitation. For the sake of convenience in the Naga Hills the three reserved forests namely, Desoi valley and Rangapahar reserved forest were under the control of D.F.O. Sibsagar and Intanki forest was under the control of D.F.O. Nowgong. In 1931, Deputy Commissioner Naga Hills, Mr. Martins, the Divisional Forest Officer (D.F.O), Sibsagar was allowed to inspect the forests in the Naga Hills which were protected by the executive order, with a view to advising what should be protected and what should be reserved or what should be deforested. It was also discussed as to how continuous water supply should be provided for the extension of terrace cultivation. The British forest policy, with both exploitation and conservation in view, had begun to give preferential treatment 
to some tree species over the others thereby affecting the diversity of the forests. The principle followed in the exploitation of the forests was to retain all the valuable species which formed the over wood and remove all the inferior species which generally formed underwood. In most of the reserves, unsystematic exploitation was carried on from time to time both under the permit system by purchasers and department. Deforestation took place to meet the needs of the main consumers of forest produce under the British administration. The demands of the consumers had direct as well as indirect impact in the form of gradual depletion of forest of Nagaland district of Assam.

\section{Railways And Deforestation}

One of the main consumers of forests is the Railways. The construction of railways had a dual impact on Indian forests. Railways hastened their destruction but also provided a stimulus for conservation. Railways spread and forest growth disappeared with incredible rapidity within the reach of the railway lines and even beyond, partly on account of the direct demands made on them(like the supply of railway sleepers) for the construction works and fuel demands which were frequently met by an exploitation carried on in a reckless manner. The Assam-Bengal railways started using 'Nahor' and 'Uriam' for sleepers in 1911- 12 and later 'Ajhar' also became an acceptable species. The Nambor forest and the Diphu forest, declared as reserved forests in 1878 and 1887, respectively were known to possess in large quantities the first class timbers viz; Jarul(Lagerstroemia Reginoe), Nahor (Mesua ferrea), Sam (Artocarpus Chaplasha), Paroli (Sterenspermum Chelonoides), Gunserai (Cinnamomum Glanduliferum) and Uriam (Bischoffia Javanica). Those portions of the Nambor forest reserve which contain trees such as Nahor and Ajhar were of much prospective value than those which did not contain these trees. Of course, unlike other parts of India, deforestation on a large scale did not take place in the Naga Hills due to the direct demands of railways.

The colonial power had reserved the forest tracks having valuable species of trees yet, deforested portion of reserved forest for the extension of railways. Dense evergreen forest of Diphu and Nambor reserves in the Naga Hills had to be deforested due to the requirement of strips of land for the Assam - Bengal Railway which passes through the reserves. For instance, two strips of land namely, 40 acres and 1189 acres of land which forms a portions of Diphu and Nambor reserve forests respectively under Barpathar Mauza in the Naga hills had to be disforested for the Assam - Bengal Railways in 1895. The Assam - Bengal Railway Company (formed in1892) laid several railway lines. There are three main section constructed by this company: one from Chittagong to Cachar, another in the Brahmaputra valley from Guwahati to Tinsukia and the third from Lumding to connect the first two sections. In 1881, the Assam Railways and Trading Company started the construction of a Railway line from Dibrugarh to Sadiya. In May 1882, the first time in the history of the province of Assam a metre gauge Locomotive passed between Dibrugarh steamerghat and Jaipur road. By 1884, the railway line was extended by a branch line from Doom Dooma to Makum. By 1909, that railway was extended to Saikhowa. ${ }^{1}$ The Jorhat Provincial Railways laid the Jorhat - Nimati and the Jorhat - Mariani sections of the railway in 1883. In 1894, the Tezpur- Balipara light Railway was opened. In 1891 there were only 114 miles of railway I Assam. By $1902-03$ the figure had risen to 715 miles and ten years later, the railway system in Assam extended over 870 miles. By 1911 - 12, railway network in Assam covered 871.5 miles.

\section{Railways Network In Assam 1911-12}

\begin{tabular}{|l|l|l|}
\hline \multicolumn{1}{|c|}{ Railway system } & \multicolumn{1}{|c|}{ Gauges } & \multicolumn{1}{|c|}{ Miles } \\
\hline 1. Dhubri-Guahati section of East Bengal Railways. & $3^{\prime}-3 / 8^{\prime}$ & 160.7 \\
\hline 2. Assam - Bengal Railway (Assam portion) & $3^{\prime}-3 / 8^{\prime \prime}$ & 569.2 \\
\hline 3. Jorhat Provincial State Railway. & $2^{\prime}$ & 30.6 \\
\hline 4. Dibru - Sadiya Railway & $3^{\prime}-3 / 8^{\prime \prime}$ & \\
(I) Saikhowa Ghat branch & & 86.0 \\
(II) Ledo- Tikal, Margherita Colliery Railway & & 5.5 \\
\hline 5 Tezpur - Balipara Railway & $2^{\prime}-6^{\prime}$ & 20.1 \\
\hline Total & & 871.5 \\
\hline
\end{tabular}

Each mile of railway construction required 860 sleepers and the average effective life of each sleeper was calculated between 12 to 14 years. Therefore, it is estimated that the sleeper requirement of 871.5 miles of railways in Assam would require approximately 3, 48,600 number of sleepers. The extent of deforestation the railway system has caused in Assam was very significant. There is a reference in the Annual Report of a joint inspection of the timber treatment plant at Mariani junction on the Assam - Bengal Railways. The results were found satisfactory and possibly the railways would be prepared to take all sleepers they required from the reserves of the Lakhimpur and Sibsagar division. 


\section{Production Of Railway Sleepers In 1920's}

The following table shows the production of railways sleepers during early 1920s:

\begin{tabular}{|c|l|l|l|c|}
\hline Year & $\begin{array}{c}\text { No. of B.C. } \\
\text { sleepers }\end{array}$ & $\begin{array}{c}\text { No of M.C. } \\
\text { sleepers }\end{array}$ & $\begin{array}{c}\text { Special } \\
\text { sleepers }\end{array}$ & Total \\
\hline $1919-20$ & - & 13,658 & 21,725 & 42,213 \\
\hline $1920-21$ & - & 14,532 & 20,839 & 42,667 \\
\hline $1921-22$ & - & 7,179 & 55,057 & 90,576 \\
\hline $1922-23$ & 3,250 & 18,839 & 26,567 & 134,555 \\
\hline $1923-24$ & 27,243 & & & \\
\hline
\end{tabular}

The next quinquennial review reports from 1924-25 to 1928-29 tell us that an overall 8, 50,282 various types of sleepers were produced. It also informs that a contract for supplying 10 lakh sleepers of miscellaneous species had been entered into which would ensure a sustain demand of 2 to 3 lakhs of sleeper annually. The annual report for the year 1926-27 recorded production of 102,095 B.G. (broad gauge) sleeper, 50,203 M.G (metre gauge) sleepers and 21,756 special sleepers worth Rs. 9,53,400. The following year, 305,457 sleepers were supplied to the Eastern-Bengal and Assam-Bengal Railways. In the year 1928-29, some 1,75,607 railway sleepers of various specification were supplied to the railways. The Eastern circle comprising Lakhimpur, Darrang, and Sibsagar supplied 3, 49,804 railway sleepers in the year 1929-30.

\section{Conclusion}

Thus in spite of desiccationist and conservative ideas prevailing at that point of time, Imperial exigencies led to the depletion of forest cover on a large scale. Forests, which have been declared as reserve forests earlier, were de-reserved as and when commercial or administrative need came up. It, is therefore, suggested that in addition to other factors timber consumption by Assam railways resulted in the reduction of valuable timber in Assam and Nagaland forests.

\section{References}

[1]. Gadgil,M \& Guha, R.(1992), This fissured Land: An Ecological History of India, OUP, p119.

[2]. E.P.Stebbing, (1922), The forests of India, OUP Vol.1, p. 63

[3]. R.Guha, (1983), 'Forestry in British and Post-British India: A Historical Analysis', in Economic and Political Weekly, Vol.XVIII, No. 44, p. 1883.

[4]. Goswami, Shrutidev, (1987), Aspects of Revenue Administration in Assam, Mittal Publications, p. 116.

[5]. Gustav Mann, Progress Report of the Forest Administration in the Province of Assam., 1874-75, p. 2.(hereafter PRFAA).

[6]. ASP, Rev. A, Revenue Dept.January, 1913.

[7]. Rajiv Handique, (2004), British Forest Policy in Assam, N.Delhi, p. 136.

[8]. B. Ribbentrop, (1900), Forestry in India, Simla, p. 61

[9]. Fly Leaf, Collection XXX, Forest Dept. No.14/7381, 1896-97, Nagaland State Archives

[10]. Allen,B.C, (1905), Gazetteer of Bengal and North East India, p.89.

[11]. PRFAA, 1918-19, Shillong, dated, September, 1919, p.26.

[12]. QRFAA, 1919-20 to 23-24, p.7

[13]. QRFAA, 1924-25 to 28-29, p.5

[14]. PRFAA, 1926-30, Shillong, dated August, 21-23, p.10-12.

[15]. Assam Administrative Report, 1911-12. 